\title{
Article
}

\section{A brief review on frictional pressure drop reduction studies for laminar and turbulent flow in helically coiled tubes}

Fsadni, Andrew, Whitty, Justin and Stables, Matthew

Available at http://clok.uclan.ac.uk/19602/

Fsadni, Andrew ORCID: 0000-0003-3047-2714, Whitty, Justin ORCID: 00000003-1002-5271 and Stables, Matthew ORCID: 0000-0002-9971-9458 (2016) A brief review on frictional pressure drop reduction studies for laminar and turbulent flow in helically coiled tubes. Applied Thermal Engineering, 109 (Part A). pp. 334-343. ISSN 1359-4311

It is advisable to refer to the publisher's version if you intend to cite from the work. http://dx.doi.org/10.1016/j.applthermaleng.2016.08.068

For more information about UCLan's research in this area go to http://www.uclan.ac.uk/researchgroups/ and search for <name of research Group>.

For information about Research generally at UCLan please go to http://www.uclan.ac.uk/research/

All outputs in CLoK are protected by Intellectual Property Rights law, including Copyright law. Copyright, IPR and Moral Rights for the works on this site are retained by the individual authors and/or other copyright owners. Terms and conditions for use of this material are defined in the policies page.

\section{CLoK}

Central Lancashire online Knowledge www.clok.uclan.ac.uk

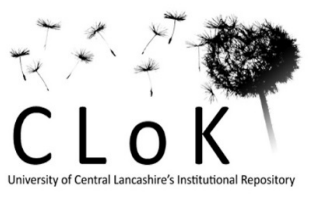




\section{Accepted Manuscript}

A brief review on frictional pressure drop reduction studies for laminar and turbulent flow in helically coiled tubes

Andrew Michael Fsadni, Justin P.M. Whitty, Matthew A. Stables

PII:

S1359-4311(16)31422-3

DOI: http://dx.doi.org/10.1016/j.applthermaleng.2016.08.068

Reference: ATE 8867

To appear in:

Applied Thermal Engineering

\section{APPLIED}

THERMAL

ENGINEERING

Received Date: $\quad 10$ June 2016

Revised Date: $\quad 10$ August 2016

Accepted Date: $\quad 11$ August 2016

Please cite this article as: A.M. Fsadni, J.P.M. Whitty, M.A. Stables, A brief review on frictional pressure drop reduction studies for laminar and turbulent flow in helically coiled tubes, Applied Thermal Engineering (2016), doi: http://dx.doi.org/10.1016/j.applthermaleng.2016.08.068

This is a PDF file of an unedited manuscript that has been accepted for publication. As a service to our customers we are providing this early version of the manuscript. The manuscript will undergo copyediting, typesetting, and review of the resulting proof before it is published in its final form. Please note that during the production process errors may be discovered which could affect the content, and all legal disclaimers that apply to the journal pertain. 
1

2

3

4

5

6

7

8

9

10

11

12

13

14

15

16

17

18

19

20

21

22
Title: A brief review on frictional pressure drop reduction studies for laminar and turbulent flow in helically coiled tubes

Authors: Andrew Michael Fsadni*, Justin P.M. Whitty, Matthew A. Stables

*Corresponding author

\section{Contact details:}

Address: University of Central Lancashire, School of Engineering, Rm. KM124, Preston, UK, PR1 2HE

Email: afsadni@uclan.ac.uk

Tel: +441772893812 
23 A brief review on frictional pressure drop reduction studies for laminar and turbulent

\title{
flow in helically coiled tubes
}

\begin{abstract}
This review, summarises the pertinent literature on drag reduction (DR) in laminar and turbulent flow in coiled tubes. Due to their compact design, ease of manufacture and superior fluid mixing properties, helically coiled tubes are widely used in numerous industries. However, flow through coiled tubes yields enhanced frictional pressure drops and thus, drag reduction is desirable as it can: decrease the system energy consumption, increase the flow rate and reduce the pipe and pump size. The main findings and correlations for the friction factor are summarised for drag reduction with the: injection of air bubbles and addition of surfactant and polymer additives. The purpose of this study is to provide researchers in academia and industry with a concise and practical summary of the relevant correlations and supporting theory for the calculation of the frictional pressure drop with drag reducing additives in coiled tubes. A significant scope for future research has also been identified in the fields of: air bubble and polymer drag reduction techniques.
\end{abstract}

Keywords: Helically coiled tube, drag reduction, frictional pressure drop, surfactants, polymer solutions.

\section{Introduction}

Due to their compact design, ease of manufacture and high efficiency in heat and mass transfer, helically coiled tubes are widely used in a number of industries and processes such as in the food, nuclear, aerospace and power generation industries and in heat recovery, refrigeration, space heating and air-conditioning processes. Due to the formation of a secondary flow, which inherently enhances the mixing of the fluid, helically coiled tube heat exchangers are known to yield improved heat transfer characteristics when compared to straight tube heat exchangers. The secondary flow, which finds its origins in the centrifugal force, is perpendicular to the axial fluid direction and reduces the thickness of the thermal boundary layer. However, for single and multiphase flows, the secondary flow yields a substantial increase in the frictional pressure drop, which often results in diminished system efficiencies (due to enhanced pumping power requirements). For air-water two-phase bubbly flow in helically coiled tubes, Akagawa et al. (1971) reported frictional pressure drops in the range of

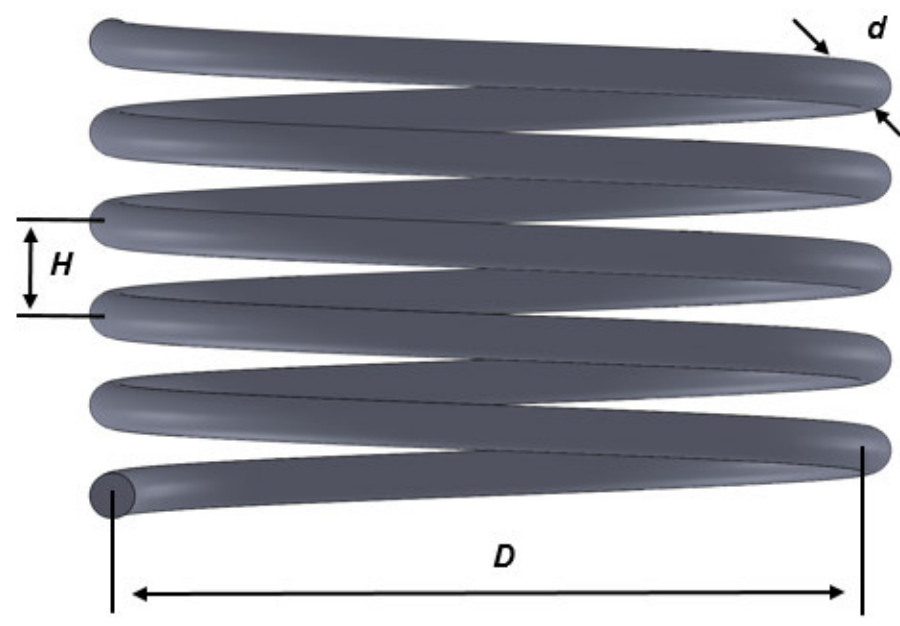


1.1 to 1.5 times greater than those in straight tubes, ceteris paribus, whilst, with the use of nanofluids, such a penalty could nullify the enhanced efficiencies gained with the dispersion of nanoparticles in the base fluid (Aly, 2014). Moreover, due to the secondary flow, the flow characteristics are significantly different to those in straight tubes. Whereas in straight tubes the transition from laminar to turbulent flow occurs at Reynolds numbers in the region of 2500 , the transition in curved tubes takes place at higher Reynolds numbers. The critical Reynolds number (Eq. (1)) is used to determine the transition of the flow from laminar to turbulent flow (Ito, 1959).

$R e_{\text {crit }}=2 E 4 \delta^{0.32}$

where $\delta$ is the curvature ratio defined through Eq. (2).

$\delta=\frac{d_{t}}{D_{c}}$

For $\delta^{-1}<8.6 \mathrm{E} 2$ whilst for $\delta^{-1}>8.6 \mathrm{E} 2, R e_{\text {crit }}$ for a curved tube is equal to that for a straight pipe.

Another dimensionless number, unique to coiled tubes, is the Dean number, given in Eq. (3). It is used to characterise the flow in curved tubes and quantifies the magnitude of the secondary flow due to the centrifugal force (Mohammed and Narrein, 2012).

$D e=\operatorname{Re} \sqrt{\delta}$

The performance of coiled tubes is a complex function of the coil design parameters (Fig. 1) as well as the resultant pressure drop. Therefore, drag reduction (DR) techniques could be particularly beneficial for systems with curved tubes. Intriguingly, whilst numerous investigations have been reported on DR in straight channels and pipelines with the: injection of air bubbles (Nouri et al., 2013; Fujiwara et al., 2004), dispersion of surfactants (Gasljevic and Matthys, 1997) and polymers (Wei and Willmarth, 1992; Al-Sarkhi and Hanratty, 2001), there is a paucity of research in the field of curved tubes. Moreover, researchers have reviewed the frictional DR techniques in straight channels and pipes (Merkle and Deutsch, 1992; Al-Sarkhi, 2010; Murai, 2014) whilst the sole study that reviewed DR in curved tubes was presented by Broniarz-Press et al. (2007). However, the latter focussed on the application of DR surfactant and polymer additives and hence, did not provide a holistic review of the relevant studies. The aim of the current study is to critically review the experimental and numerical studies done on DR in single-phase (water) laminar and turbulent flow through coiled tubes. Such studies are categorized in three sections, representing the pertinent techniques reported. Moreover, this paper complements the earlier review undertaken by the authors of the present study (Fsadni and Whitty, 2016), as it further elucidates the underpinning physics of air-water bubbly flow through curved tubes. It is the authors' hope that this review will be useful to both academics and industry based engineers through the provision of a concise report on the relevant current knowledge.

\section{Injection of air bubbles}

Over the past 40 years, the injection of microbubbles in the turbulent boundary layer has been investigated by numerous investigators, with the first study reported by McCormick 
and Bhattacharyya (1973) who investigated the DR to a submersible hull. As summarised in Table 1, Shatat et al. (2009a\&b) were the first to investigate DR with the injection of air bubbles in laminar and turbulent low through helically coiled tubes. They reported a diminished DR efficiency (Eq. (4)) over that of straight tubes. Such results were more significant with higher curvature ratios whilst, the DR increased with higher air volumetric void fractions $(V F)$ and decreased with higher Re numbers (Fig. 2). Moreover, DR was limited to turbulent flow. Similar results were reported by Saffari et al. (2013) who measured a $25 \%$ DR at a $V F$ of 0.09 in turbulent flow bubbly flow. The latter study did not investigate the DR with straight tubes. However, their experimental parameters are comparable to those used by Nouri et al. (2013) who reported a DR of $35 \%$ for a $V F$ of 0.09 in straight tubes.

$$
D R=100\left(\frac{f_{l}-f_{t p}}{f_{l}}\right)
$$

where $f_{l}$ is the Fanning friction factor for single-phase flow and $f_{t p}$ is the friction factor for two-phase flow.

For a straight vertical pipe, Fujiwara et al. (2004) reported that, with a high $V F$ in the near-wall region, the turbulence intensity and Reynolds stress are reduced in a wide region of the pipe. The turbulence energy dissipation occurs around the bubbles due to bubble-induced eddies, whilst the diminished fluid density in the near-wall region reduces the shear stress, thus resulting in a lower system frictional pressure drop. Saffari et al. (2013) reported that in curved tubes, higher $R e$ numbers and curvature ratios, result in larger centrifugal forces which force the lower density phase (air bubbles) to migrate towards the inner tube wall region. Resultantly, the shear stress at the inner tube wall region is lower than that at the outer wall region. Hence, the uneven distribution of the air bubbles at higher $R e$ numbers and curvature ratios results in a diminished DR efficiency.

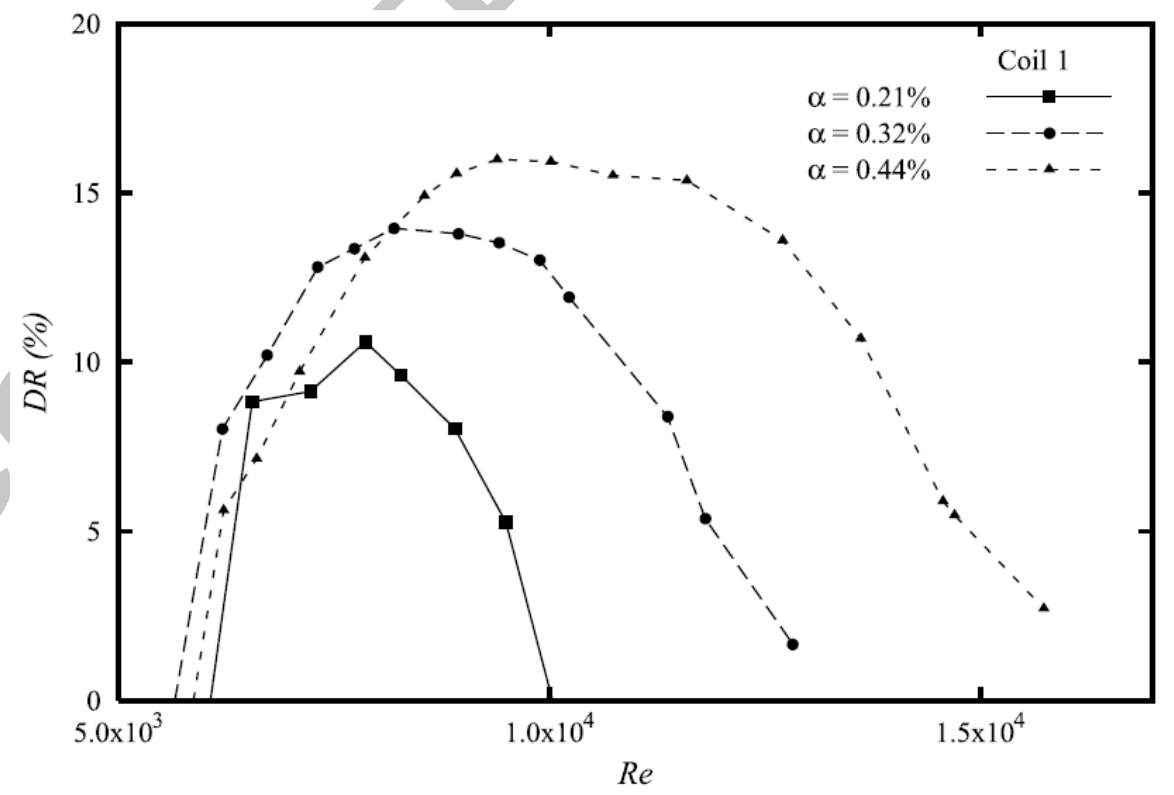

Figure 2: DR as a function of the air $V F(\alpha)$ for a curvature ratio of 0.025 (Shatat $e t$ al., 2009a. Fig. 11).

These studies are in a general agreement with relevant theory and numerous DR studies reported for channel and straight tube flow. Moreover, there is significant scope for further research in DR (in coiled tubes) as a function of the bubble diameter. In fact, for 
straight tubes and channels, some controversy surrounds the impact of bubble size on the DR, where some investigators reported the DR to be a strong function of the bubble diameter (Liu 1993; Murai et al., 2007) while other investigators reported the DR to be independent of the bubble diameter (Moriguchi and Kato, 2002; Shen et al., 2006). The relation of the bubble induced DR studies with those reviewed for two-phase gas-liquid frictional pressure drop characteristics in coiled tubes (Fsadni and Whitty, 2016) remains indeterminate. In fact, the latter investigations reported a general agreement with the Lockhart and Martinelli correlation for straight tubes, with the two-phase frictional pressure drop multiplier in excess of unity.

\section{Surfactant additives}

Surface-active agents (surfactants) are low molecular weight, viscous, non-polymer, water-based chemicals that tend to accumulate at a surface and diminish interactive forces between the molecules of the base fluid, thus reducing the surface tension. Inaba et al. (2005) reported that surfactant additives form a network structure of rod-like micelles which absorbs the turbulent energy with its flexibility and deformation, thus leading to a flow laminarisation effect. Hence, surfactants enhance the elastic properties of the fluid with the resultant increase in DR. Unlike polymer based fluids, the mechanical degradation of the micelle network at high shear stresses is completely reversed at a low flow rate. All the studies reviewed reported a DR limited to the transition and turbulent flows, with a reduced DR in curved tubes when compared to straight tubes, ceteris paribus. Such findings were attributed to the formation of the secondary flow which is largely unaffected by the surfactant additive. Gasljevic and Matthys (1999) reported that for a velocity range of $2-5 \mathrm{~m} / \mathrm{s}$, the secondary flow effects were separated from the turbulence effects through the use of the turbulence reduction - drag (TRD) method given in Eq. (5). This yielded a TDR of 70\% (turbulence suppression) for both coiled and straight tubes (Fig. 3). In contrast, Broniarz-Press et al. (2003) reported that the tube curvature effect on the friction factor was diminished due to the damping of the secondary flows streams. A broad analogy can be made with nanofluid flow in coiled tubes where, nanoparticles were also attributed to the mitigation of the secondary flow (Fsadni and Whitty, 2016).

$$
T R D=\frac{F C_{b f, t b}-F C_{D R F}}{F C_{b f, t b}-F C_{b f, l m}}
$$

where $I m$ refers to the laminar flow of the base fluid (without the DR additives) at the same $R e$ number and $t b$ refers to the turbulent flow of the base fluid. 


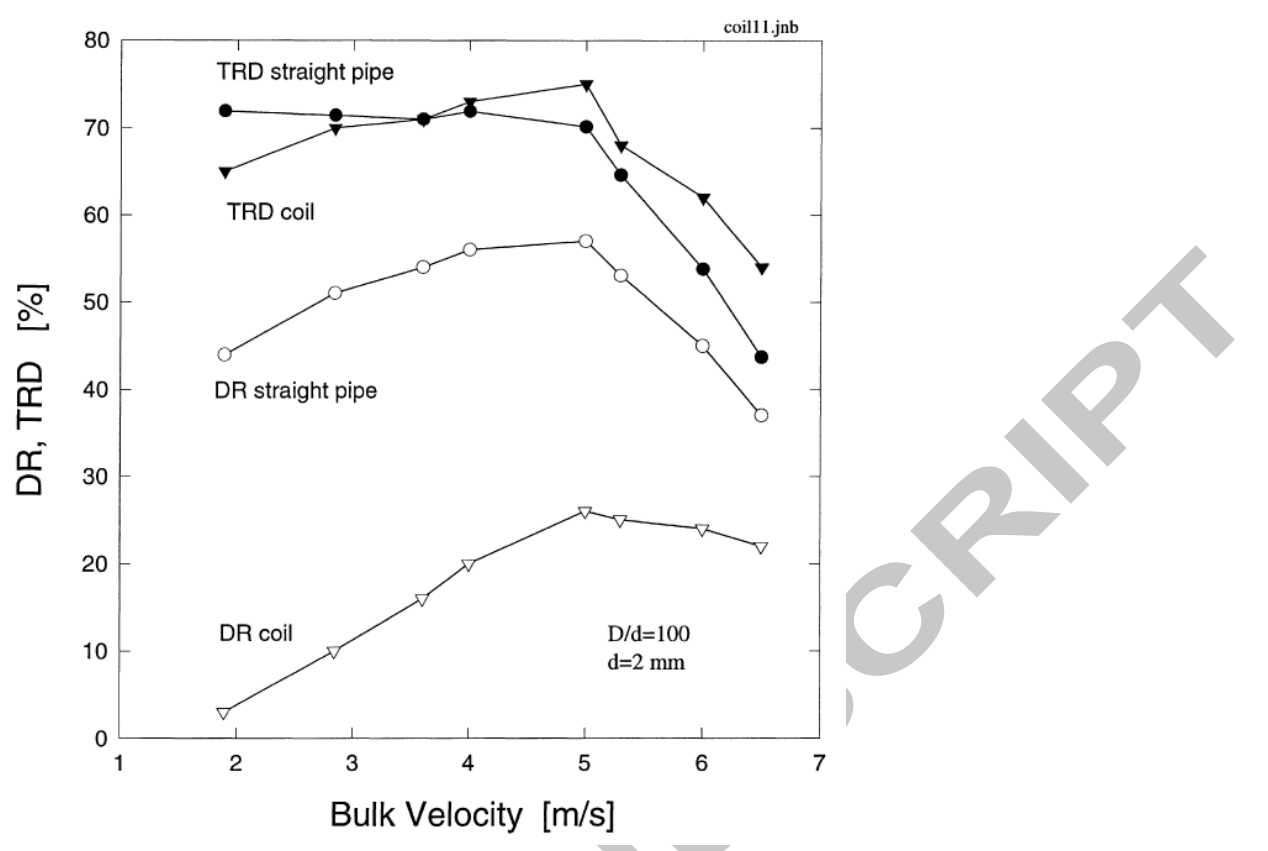

Figure 3: Friction reduction in terms of $D R$ and $T R D$ for a coiled and straight pipe (Gasljevic and Matthys, 1999 Fig. 4).

At laminar flow conditions, Weber et al. (1991) and Gasljevic and Matthys (2009) reported an increase in the frictional pressure drop (compared to water). This was attributed to the enhanced solution viscosity. There is a general agreement amongst the studies reviewed that lower coil curvatures and higher surfactant concentrations yielded higher DR efficiencies. Moreover, Kamel and Shah (2013) reported that at higher concentrations, surfactant solutions are more resistant to mechanical degradation and hence, yield higher DR efficiencies at increased $R e$ numbers. Therefore, Broniarz-Press et al. (2002) reported that DR is a strong function of the surfactant concentration, with DR evident above a critical concentration. Inaba et al. (2005) reported that the dynamic nature of surfactant DR additives render them particularly relevant for heating systems. However, such comments should be considered in light of the fact that these additives are known to yield reduced heat transfer coefficients. Kostic (1994) attributed this phenomenon to the non-homogenous turbulence resulting from the flow-induced anisotropicity of the highly structured micelle network. Weber et al. (1991), Inaba et al. (2000\&2005), Aly et al. (2006) and Kamel and Shah (2013) presented correlations for the calculation of the friction factor in surfactant solutions. Due to the Non-Newtonian properties of these solutions $(C>3,000 \mathrm{ppm})$, correlations were developed as a function of the modified or generalised $R e$ and $D e$ numbers.

\section{Polymers additives}

Toms (1948) reported that the addition of minute concentrations of high-molecular weight, long chain and flexible polymers to a Newtonian solvent can yield significant DR properties. Whilst it is widely accepted that the DR efficiency is a strong function molecular weight and distribution, molecular structure and solubility, the underpinning physics are known to be complex and not well-understood (Gallego and Shah, 2009). Factors such as shear thinning, viscoelasticity and molecular stretching have been suggested to diminish the turbulence in the fluid (Bird et al., 1987), thus resulting in DR.

Shah and Zhou (2001) stated that the DR mechanism of polymers occurs at the boundary layer and therefore is typically more effective in smaller tube diameters. Moreover, 
in agreement with the findings reported for air-bubble injection, DR efficiency decreases with higher coil curvatures. This is inherent to the effects of the centrifugal force on the fluid flow. DR is also a function of the ability of the polymer to resist thermal and mechanical degradation. Shah et al. (2006) reported that at a volume concentration of $0.07 \%$, the widely used partially hydrolysed polyacrylamide (PHPA) copolymer (Nalco ASP-820) yielded the highest DR (65\%). At this concentration, it was assumed that the fluid behaviour is quasiNewtonian. This concentration was subsequently used by Gallego and Shah (2009) and Ahmed Kamel (2011). Gallego and Shah presented a unique generalised friction pressure correlation for DR polymer solutions in coiled tubes. Their correlation assumed that the appropriate characteristic polymer solution viscosity is relative to the zero shear rate viscosity, that is, the shear stress required to deform the polymer molecule from its equilibrium state.

The effect of the polymer concentration is also function of the specific physical conditions of the flow. Resultantly, Shah and Zhou (2001) reported that for large tubes and low flow rates, high concentrations of polymer additives increased the fluid drag and delayed the onset of DR (Fig. 4). For small diameter tubes, the opposite effect was reported and thus, a higher polymer concentration increased the DR.



Figure 4: Effect of polymer concentration (Xanthan) on DR ratio (Shah and Zhou, 2001 Fig. 5).

The effect of elevated temperatures on the DR of polymers in coiled tubes was investigated by Gallego and Shah (2009) and Ahmed Kamel (2011) who reported that, in contrast to the findings for straight tubes, DR remained quasi-constant (Ahmed Kamel) or increased (Gallego and Shah) with temperature. It is widely accepted that with polymer solutions in straight tubes, elevated temperatures yield a drop in the DR. This is due to a combination of factors, such as the deterioration of the solvent-polymer interaction and the diminishing of the macromolecule size (Clifford and Sorbie, 1985; Nesyn et al., 1989). In view of this complexity and the paucity of studies for curved tubes, Gallego and Shah (2009) and Ahmed Kamel (2011) concluded that the origins of their results are indeterminate and thus require further investigation. In contrast to the numerous studies on polymer DR additives to gas-liquid flows in straight tubes (Sylvester and Brill, 1976; Al-Sarkhi and 
Soleimani, 2004), there are no related studies for coiled tubes. This presents further scope for future research in the field of two-phase flow in coiled tubes.

\begin{tabular}{|c|c|c|c|c|c|}
\hline $\begin{array}{c}\text { Investigators } \\
\& \\
\text { Methodology }\end{array}$ & Year & $\begin{array}{c}\text { Flow configuration } \& \\
\text { coil geometry }\end{array}$ & $\begin{array}{l}\text { Mean bubble } \\
\text { size }\end{array}$ & $\begin{array}{c}\text { Void fraction } \\
\text { or } \\
\text { concentration }\end{array}$ & Drag reduction \\
\hline \multicolumn{6}{|c|}{ Air bubbles } \\
\hline $\begin{array}{l}\text { Shatat et al. } \\
\text { Experimental }\end{array}$ & $\begin{array}{c}2009 a \\
\& b\end{array}$ & $\begin{array}{c}d_{t}=20 \mathrm{~mm} \\
D_{c}=800,400,200 \mathrm{~mm} \\
\delta=0.025,0.05,0.1 \\
H=40 \mathrm{~mm} \\
1,000<R e<100,000 \\
W e<1.0 \\
\text { Laminar and turbulent } \\
\text { bubbly flow }\end{array}$ & $\begin{array}{c}d_{b, m}=0.06 \mathrm{~mm} \\
d_{b, \max }=0.174 \mathrm{~m} \\
\mathrm{~m} \\
\text { No } \\
\text { deformation of } \\
\text { bubbles. }\end{array}$ & $\begin{array}{c}0.21<V F<0.44 \\
\%\end{array}$ & $\begin{array}{l}16 \% \text { for } \delta=0.025 \text {. For a } \\
\text { straight pipe } 51 \% D R \text {, } \\
\text { ceteris paribus. } \\
\text { DR effect starts at the } \\
\text { critical } R e \text { number. } \\
\text { DR increases with } V F \\
\text { for all cases. } \\
\text { The curvature of the } \\
\text { coils had a negative } \\
\text { effect on drag } \\
\text { reduction. } \\
\text { The Re number } \\
\text { corresponding to the } \\
\text { maximum DR was } \\
\text { shifted to a higher value } \\
\text { (compared to a straight } \\
\text { tube). This shift } \\
\text { increased with an } \\
\text { increase in the curvature } \\
\text { of the coil. }\end{array}$ \\
\hline $\begin{array}{l}\text { Saffari et al. } \\
\text { Experimental }\end{array}$ & 2013 & $\begin{array}{c}d_{t}=12,19 \mathrm{~mm} \\
D_{c}=200 \mathrm{~mm} \\
\delta=0.06,0.095 \\
H=24 \mathrm{~mm} \\
P=0.101 \mathrm{MPa} \\
10,000<R e<50,000 \\
\text { Turbulent bubbly flow }\end{array}$ & $\begin{array}{c}d_{b, m}=0.27 \mathrm{~mm} \\
\text { Bubble } \\
\text { diameter } \\
\text { decreased at } \\
\text { higher } R e \\
\text { numbers. At } \\
\text { lower } R e \\
\text { numbers, } \\
\text { bubbles were } \\
\text { less spherical } \\
\text { in shape (less } \\
\text { rigid). This is } \\
\text { due to the } \\
\text { influence of } \\
\text { flow stress and } \\
\text { reduced } \\
\text { surface } \\
\text { tension (in } \\
\text { comparison to } \\
\text { the smaller } \\
\text { bubbles). }\end{array}$ & $0.01<V F<0.09$ & $\begin{array}{l}\text { DR increased with } \\
V F \text { with a maximum } \\
\text { of } 25 \% \text { at a } V F \text { of } \\
9 \% \text { DR diminished } \\
\text { with higher } R e \\
\text { numbers. } \\
\text { At a low } V F \text { of } 1 \% \text {, a } \\
\text { DR of } 9 \% \text { was } \\
\text { measured. } \\
\text { DR diminished with } \\
\text { an increase in the } \\
\text { curvature of the coil. }\end{array}$ \\
\hline $\begin{array}{l}\text { Saffari and } \\
\text { Moosavi } \\
\text { Numerical } \\
\text { (Eulerian- } \\
\text { Eulerian } \\
\text { multiphase } \\
\text { model) }\end{array}$ & 2014 & $\begin{array}{c}d_{t}=16,25,40 \mathrm{~mm} \\
D_{c}=100,200 \mathrm{~mm} \\
\delta=0.08,0.125,0.20 \\
H=20,60 \\
15,000<\operatorname{Re}<80,000 \\
\text { Turbulent bubbly flow }\end{array}$ & $\begin{array}{c}d_{b, m}=0.1 \mathrm{~mm} \\
\text { No } \\
\text { deformation of } \\
\text { bubbles. }\end{array}$ & $0.01<V F<0.09$ & $\begin{array}{l}\text { Due to a reduction in } \\
\text { the mixture density, } \\
\text { higher } V F \text { yields } \\
\text { lower pressure drops, } \\
\text { shear stress and } \\
\text { friction coefficient. }\end{array}$ \\
\hline
\end{tabular}




\begin{tabular}{|c|c|c|c|c|c|}
\hline \multicolumn{6}{|c|}{ Surfactant solutions \& Foam fluids } \\
\hline \multirow[t]{2}{*}{$\begin{array}{l}\text { Weber et al. } \\
\text { Experimental }\end{array}$} & \multirow[t]{2}{*}{1991} & $\begin{array}{c}d_{t}=10.5,16.5 \mathrm{~mm} \\
157<D_{c}<454 \mathrm{~mm} \\
0.105<\delta<0.036 \\
N=12,18,34,39 \\
1,500<R e<100,000 \\
6,750<R e_{c r i t}<9,480 \\
30^{\circ} \mathrm{C}<T<90^{\circ} \mathrm{C} \\
\text { Laminar and turbulent }\end{array}$ & $\begin{array}{l}\text { Fluid was } \\
\text { assumed to be } \\
\text { quasi- } \\
\text { Newtonian. }\end{array}$ & $\begin{array}{c}C=62.5 ; 250 ; 1 \\
000 \text { ppm } \\
\text { Habon in } \\
\text { water. }\end{array}$ & $\begin{array}{l}\text { For laminar flow, } \\
\text { surfactant additives } \\
\text { increased the fluid } \\
\text { drag. } \\
\text { For turbulent flow the } \\
\text { increase in DR with } \\
C \text { was marginal. } \\
\text { DR in curved tubes } \\
\text { diminished at a lower } \\
R e \text { value than that in } \\
\text { straight tube, ceteris } \\
\text { paribus. }\end{array}$ \\
\hline & & \multicolumn{4}{|c|}{$f_{\text {Fanning }}=\frac{1855 \delta^{\frac{2}{3}}}{R e}+0.011$} \\
\hline $\begin{array}{l}\text { Gasljevic and } \\
\text { Matthys } \\
\text { Experimental }\end{array}$ & 1999 & $\begin{array}{c}d_{t}=2 \mathrm{~mm} \\
D_{c}=200 \mathrm{~mm} \\
\delta=0.01 \\
1.8<V<7 \mathrm{~m} / \mathrm{s} \\
T=25^{\circ} \mathrm{C} \\
\text { Laminar and turbulent }\end{array}$ & $\begin{array}{l}\text { Fluid was } \\
\text { assumed to be } \\
\text { quasi- } \\
\text { Newtonian. }\end{array}$ & $\begin{array}{l}C=2,000 \mathrm{ppm} \\
\text { SPE95285 } \\
\text { (Same } \\
\text { viscosity as } \\
\text { water) }\end{array}$ & $\begin{array}{l}\text { DR in coiled tube is } \\
30 \% \text {, in a straight } \\
\text { tube } 60 \% \text {, ceteris } \\
\text { paribus. } \\
\text { Calculated } 70 \% \\
\text { reduction in } \\
\text { turbulence effects for } \\
\text { both straight and } \\
\text { coiled tubes. } \\
\text { At } V>5 \mathrm{~m} / \mathrm{s} \text { DR effect } \\
\text { diminishes due to } \\
\text { micelle degradation. }\end{array}$ \\
\hline \multirow[t]{2}{*}{$\begin{array}{l}\text { Inaba et al. } \\
\text { Experimental }\end{array}$} & \multirow[t]{2}{*}{2000} & $\begin{array}{c}d_{t}=17.7 \mathrm{~mm} \\
D_{c}=177,300.9,442.5,885 \mathrm{~m} \\
\mathrm{~m} \\
\delta=0.02,0.04,0.059,0.1 \\
400<R e^{\prime}<200,000 \\
10^{\circ} \mathrm{C}<T<25^{\circ} \mathrm{C} \\
\theta=45^{\circ}, 90^{\circ}, 180^{\circ}, 270^{\circ} \\
\text { Laminar and turbulent }\end{array}$ & $\begin{array}{l}\text { Non- } \\
\text { Newtonian } \\
\text { viscoelastic } \\
\text { fluid. }\end{array}$ & $\begin{array}{c}530<C<1,773 \\
\text { ppm } \\
\text { Dodecyltrimet } \\
\text { hyl } \\
\text { Ammonium } \\
\text { Chloride } \\
\left(\mathrm{C}_{12} \mathrm{H}_{25} \mathrm{~N}\left(\mathrm{CH}_{3}\right.\right. \\
\left.)_{3}=263.89\right) \\
\text { and Sodium } \\
\text { Salicylate } \\
\left(\mathrm{C}_{7} \mathrm{H}_{5} \mathrm{NaO}_{3}=1\right. \\
60.10) \text { in } \\
\text { water }\end{array}$ & $\begin{array}{l}\text { No DR at laminar } \\
\text { flow conditions, } \\
\text { whilst DR at } \\
\text { turbulent } \\
\text { conditions was less in } \\
\text { relation to that in a } \\
\text { straight pipe. } \\
\text { At a } C \text { of } 561 \mathrm{ppm} \text { no } \\
\text { DR was measured. } \\
\text { Due to the } \\
\text { suppression of } \\
\text { turbulence vortexes, } \\
\text { the heat transfer } \\
\text { coefficient was less } \\
\text { than that for water. }\end{array}$ \\
\hline & & \multicolumn{4}{|c|}{$\begin{array}{c}f_{\text {Darcy }}=6.75\left(\frac{D_{c}}{d_{t}}\right)^{-0.560} \theta^{0.146} D e^{-0.5} \\
0.02<\delta<0.05 ; 45^{\circ}<\theta<270^{\circ} ; C>1,000 \mathrm{ppm} \\
(S D=9.17 \%)\end{array}$} \\
\hline $\begin{array}{l}\text { Broniarz-Press } \\
\qquad \text { et al. } \\
\text { Experimental }\end{array}$ & 2002 & $\begin{array}{c}0.0219<\delta<0.0792 \\
1,200<R e_{\text {gen }}<30,000 \\
70<D e^{\prime}<3,000 \\
T=303,323,333 \mathrm{~K} \\
\text { Laminar and turbulent }\end{array}$ & $\begin{array}{c}\text { Non- } \\
\text { Newtonian } \\
\text { viscoelastic } \\
\text { fluid. }\end{array}$ & $\begin{array}{c}W C=0.1,0.25 \\
\% \\
\text { Cationic } \\
\text { Hexadecyltrim } \\
\text { ethylammoniu } \\
\text { m chloride } \\
\text { (HTAC) and }\end{array}$ & $\begin{array}{l}\text { DR is only evident } \\
\text { above a critical } C \text {. } \\
\text { This contrasts to } \\
\text { polymers where DR } \\
\text { is significant with } \\
\text { minute } C \text { of polymer } \\
\text { additives. }\end{array}$ \\
\hline
\end{tabular}




\begin{tabular}{|c|c|c|c|c|c|}
\hline & & & & $\begin{array}{c}\text { anionic soaps, } \\
\text { sodium \& } \\
\text { potassium } \\
\text { oleates with } \\
W C=2.5,7 \% \\
\text { sodium } \\
\text { salicylate } \\
\text { (NaSal), } \\
\text { sodium } \\
\text { chloride, and } \\
\text { potassium } \\
\text { chloride } \\
\text { solution } \\
\text { additives in } \\
\text { water. }\end{array}$ & $\begin{array}{l}\text { With polymer } \\
\text { additives, DR is only } \\
\text { evident when the } \\
\text { molar mass is above a } \\
\text { critical value. } \\
\text { Cylindrical micelles } \\
\text { stabilise the } \\
\text { mechanisms of } \\
\text { curved flow. } \\
\text { DR increases with } \\
\text { higher turbulence. }\end{array}$ \\
\hline $\begin{array}{l}\text { Broniarz-Press } \\
\text { et al. } \\
\text { Experimental }\end{array}$ & 2003 & $\begin{array}{c}0.0219<\delta<0.0792 \\
1,200<R e_{\text {gen }}<30,000 \\
70<D e^{\prime \prime}<3,000 \\
T=303,313,333 \mathrm{~K} \\
\text { Laminar and turbulent }\end{array}$ & $\begin{array}{c}\text { Non- } \\
\text { Newtonian } \\
\text { viscoelastic } \\
\text { fluid. }\end{array}$ & 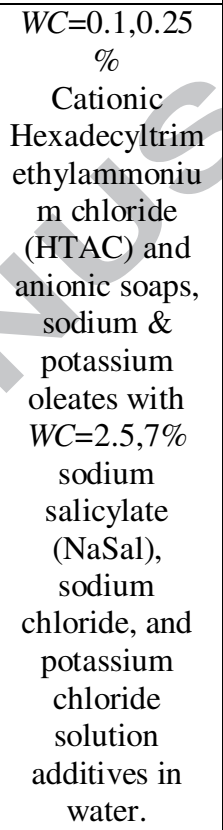 & $\begin{array}{l}\text { DR observed in } \\
\text { turbulent and } \\
\text { pseudolaminar flows. } \\
\text { Surfactant additives } \\
\text { diminished the tube } \\
\text { curvature effect on } \\
\text { the friction factor. } \\
\text { This was attributed to } \\
\text { the damping of the } \\
\text { secondary flow } \\
\text { streams. }\end{array}$ \\
\hline $\begin{array}{l}\text { Inaba } \text { et al. } \\
\text { Experimental }\end{array}$ & 200 & $\begin{array}{c}d_{t}=14.4 \mathrm{~mm} \\
D_{c}=540 \mathrm{~mm} \\
\delta=0.0267 \\
H=32 \mathrm{~mm} \\
N=10 \\
10,000<R e^{\prime}<100,000 \\
100<D e / D e^{\prime}<10,000 \\
100<G z / G z^{\prime}<10,000 \\
5^{\circ} \mathrm{C}<T<20^{\circ} \mathrm{C} \\
\text { Laminar and turbulent }\end{array}$ & $\begin{array}{c}\text { Non- } \\
\text { Newtonian } \\
\text { viscoelastic } \\
\text { behaviour at } \\
\text { high } \\
\text { concentrations } \\
(>3,000 \mathrm{ppm})\end{array}$ & $\begin{array}{c}1,000<C<3,50 \\
00 \mathrm{ppm} \\
\text { Mixture of } \\
\text { oleyldihydrox } \\
\text { yethylamineox } \\
\text { ide }(\mathrm{ODEAO}, \\
\mathrm{C}_{22} \mathrm{H}_{45} \mathrm{NO}_{3}=3 \\
71) 90 \% \text {, non- } \\
\text { ionic } \\
\text { surfactant \& } \\
\text { cetyldimethyla } \\
\text { minoaciticacid } \\
\text { betaine } \\
(\mathrm{CDMB}, \\
\mathrm{C}_{20} \mathrm{H}_{41} \mathrm{NO}_{2}=3 \\
27) 10 \% \text { as a } \\
\text { zwitterion } \\
\text { surfactant in } \\
\text { water. }\end{array}$ & $\begin{array}{l}43 \% \text { DR in the coiled } \\
\text { tube. } \\
77 \% \text { DR in a straight } \\
\text { tube. } \\
\text { This is due to the } \\
\text { secondary flow that } \\
\text { contributes towards } \\
\text { the pressure drop in } \\
\text { coiled tubes. } \\
\text { Drop in the heat } \\
\text { transfer coefficient } \\
\text { with surfactant } C \text {. } \\
\text { DR increases with } \\
\text { surfactant } C \text {. }\end{array}$ \\
\hline
\end{tabular}




\begin{tabular}{|c|c|c|c|c|c|}
\hline & & \multicolumn{4}{|c|}{$\begin{array}{l}\frac{f_{c, \text { Darcy }}}{f_{\text {st }, \text { Darcy }}}=D e^{\prime 0.42} C_{n d}^{0.11} T_{n d}^{1.5} \\
\frac{T_{\text {actual }}}{T_{\text {critical }(275 K)}} ; C_{n d}=\frac{C_{\text {actual }}}{C_{\text {critical }(1,000 p p m)}}\end{array}$} \\
\hline \multirow[t]{2}{*}{$\begin{array}{l}\text { Aly et al. } \\
\text { Experimental }\end{array}$} & \multirow[t]{2}{*}{2006} & $\begin{array}{c}d_{t}=14.4 \mathrm{~mm} \\
D_{c}=320,540,800, \mathrm{~mm} \\
0.018<\delta<0.045 \\
H=32 \mathrm{~mm} \\
N=10 \\
1,000<R e^{\prime}<100,000 \\
5^{\circ} \mathrm{C}<T<20^{\circ} \mathrm{C} \\
\text { Laminar and turbulent }\end{array}$ & $\begin{array}{l}\text { Newtonian } \\
\text { fluids for } \\
C<3,000 \text { ppm. }\end{array}$ & $\begin{array}{c}250<C<5,000 \\
\text { ppm } \\
\text { Mixture of } \\
\text { non-ionic } \\
\text { surfactant } \\
\text { oleyldihydrox } \\
\text { yethylamineox } \\
\text { ide }(\mathrm{ODEAO}, \\
\mathrm{C}_{22} \mathrm{H}_{45} \mathrm{NO}_{3}=3 \\
71) 90 \%, \& \\
\text { cetyldimethyla } \\
\text { minoaciticacid } \\
\text { betaine } \\
(\mathrm{CDMB}, \\
\mathrm{C}_{20} \mathrm{H}_{41} \mathrm{NO}_{2}=3\end{array}$ & $\begin{array}{l}\text { DR increased with } \\
\text { surfactant } C \text {, with a } \\
\text { max. of } 59 \% \text { at } \\
R e=55,350 \\
C=2678 \mathrm{ppm} \text {. } \\
\text { DR increased with } \\
\text { temperature and } \\
\text { decreased with higher } \\
\text { coil curvatures. } \\
\text { Lower DR and losses } \\
\text { in the heat transfer } \\
\text { coefficient were } \\
\text { measured when } \\
\text { compared to straight } \\
\text { tubes, ceteris paribus. }\end{array}$ \\
\hline & & \multicolumn{4}{|c|}{$\begin{array}{c}=\frac{137 \delta^{0.62}\left(1+0.94 C c^{-0.34} T c^{-1.57}\right)}{\left(1.56+\log D e^{\prime}\right)^{5.73}} \\
(S D=10 \%) \\
<1.065 ; 4<C c<14 ; 0.018<\delta<0.045\end{array}$} \\
\hline $\begin{array}{l}\text { Gasljevic and } \\
\text { Matthys } \\
\text { Experimental }\end{array}$ & 2009 & $\begin{array}{c}d_{t}=12 \mathrm{~mm} \\
\delta=0.043,0.067,0.116 \\
0.9<V<7 \mathrm{~m} / \mathrm{s} \\
T=25^{\circ} \mathrm{C} \\
\text { Laminar and turbulent }\end{array}$ & $\begin{array}{c}\text { Non- } \\
\text { Newtonian } \\
\text { viscoelastic } \\
\text { fluid. }\end{array}$ & $\begin{array}{c}C=2,000 \mathrm{ppm} \\
\text { cationic } \\
\text { surfactant } \\
\text { Ethoquad T- } \\
13 \& \\
2,000 \mathrm{ppm} \\
\text { NaSl as a } \\
\text { counterion. }\end{array}$ & $\begin{array}{l}\text { DR for turbulent flow } \\
\text { in the range of } 30- \\
40 \% \text { was measured. } \\
\text { This is less that that } \\
\text { in a straight pipe } \\
\text { where } 75 \% \text { DR was } \\
\text { measured, ceteris } \\
\text { paribus. } \\
\text { DR decreased with } \\
\text { higher curvature } \\
\text { ratios. } \\
\text { For the coil with the } \\
\text { highest curvature, at } \\
V=0.9 \mathrm{~m} / \mathrm{s} \text {, } \\
\text { pressure the } \\
\text { increased in relation } \\
\text { to that of water. This } \\
\text { was attributed to the } \\
\text { higher viscosity of } \\
\text { the surfactant } \\
\text { solution in relation to } \\
\text { water at a shear rate } \\
\text { of } 500 \mathrm{~s}^{-1} \text {. }\end{array}$ \\
\hline $\begin{array}{l}\text { Kamel and } \\
\text { Shah } \\
\text { Experimental }\end{array}$ & 2013 & $\begin{array}{c}11.0<d_{t}<63.5 \mathrm{~mm} \\
360<D_{c}<2,850 \mathrm{~mm} \\
0.01<\delta<0.031 \\
20,000<\operatorname{Re}<200,000 \\
\text { Turbulent }\end{array}$ & $\begin{array}{l}\text { Non- } \\
\text { Newtonian } \\
\text { viscoelastic } \\
\text { fluid. }\end{array}$ & $\begin{array}{c}V C=1.5,2.3,4 \\
\% \\
\text { Tallowalkyla } \\
\text { midopropyl }\end{array}$ & $\begin{array}{l}\text { DR is significant in } \\
\text { coiled tubes and } \\
\text { increases with } C \text {, } \\
\text { with a significant }\end{array}$ \\
\hline
\end{tabular}




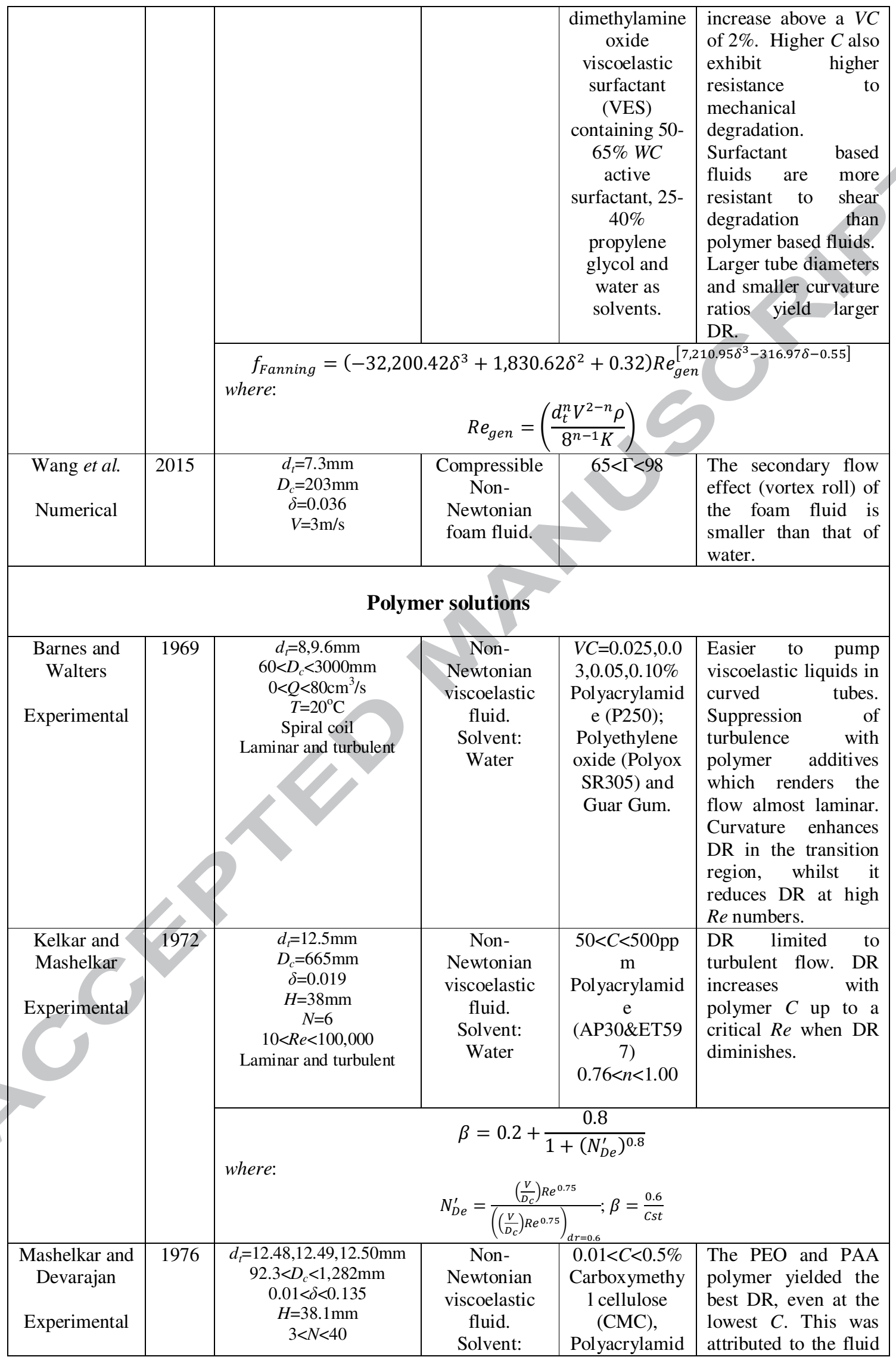




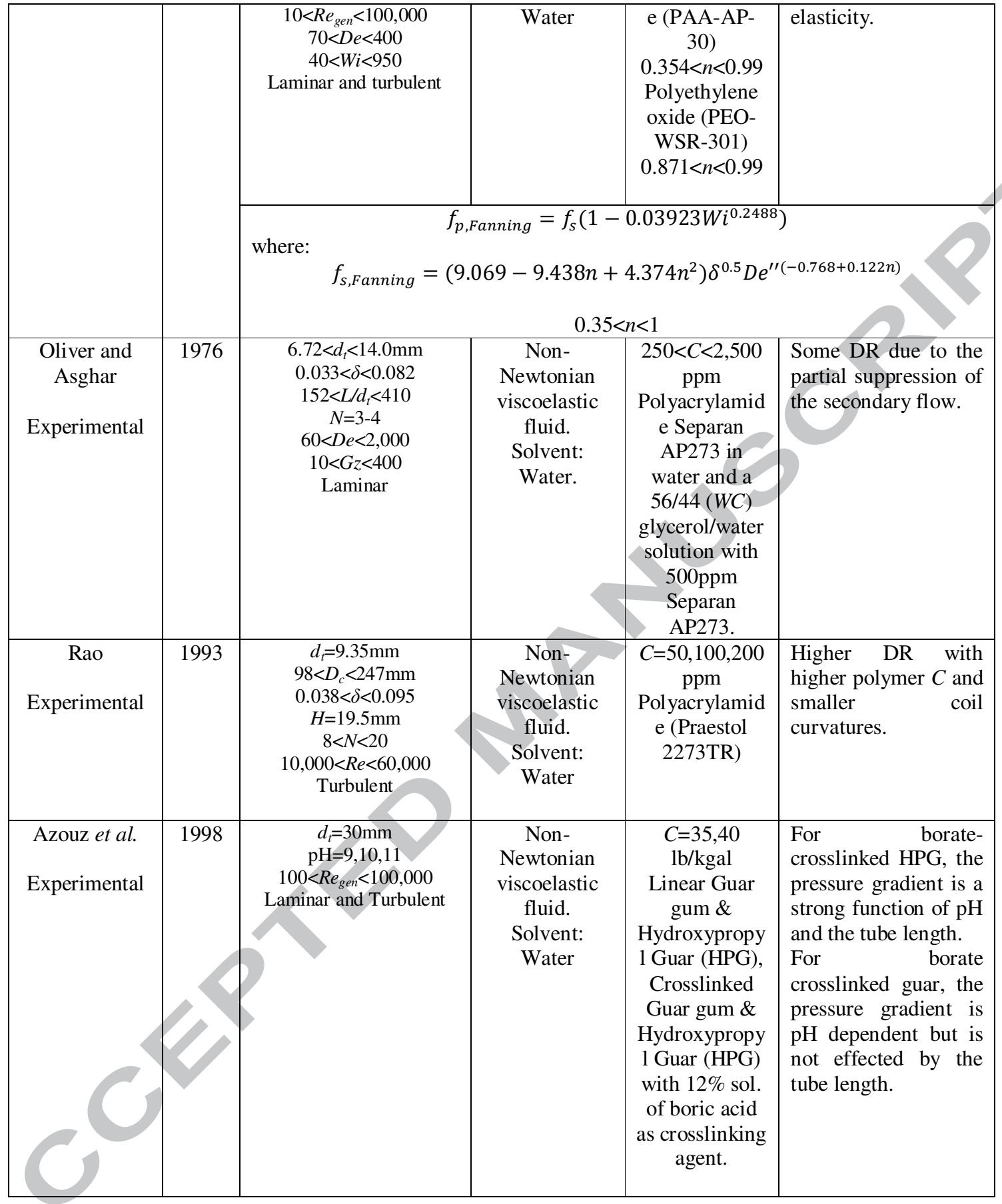




\begin{tabular}{|c|c|c|c|c|c|}
\hline $\begin{array}{c}\text { Shah and } \\
\text { Zhou } \\
\text { Experimental }\end{array}$ & 2001 & $\begin{array}{c}d_{t}=25.4,38.1,60.3 \mathrm{~mm} \\
D_{c}=121.92,182.88,281.94 \\
\mathrm{~mm} \\
\delta=0.0113,0.0165,0.0169 \\
P_{\max }=34.47 \mathrm{MPa} \\
4,000<R_{\text {gen }}<200,000 \\
\text { Laminar and Turbulent }\end{array}$ & $\begin{array}{c}\text { Non- } \\
\text { Newtonian } \\
\text { viscoelastic } \\
\text { fluid. } \\
\text { Solvent: } \\
\text { Water }\end{array}$ & $\begin{array}{c}\text { Guar } \\
C=2.397 \\
\mathrm{~kg} / \mathrm{m}^{3} \\
0.642<n<0.72 \\
C=3.595 \\
\mathrm{~kg} / \mathrm{m}^{3} \\
0.527<n<0.55 \\
C=4.793 \\
\mathrm{~kg} / \mathrm{m}^{3} \\
0.433<n<0.48 \\
3 \\
\text { partially } \\
\text { hydrolysed } \\
\text { polyacrylamid } \\
\text { e (PHPA) } \\
C=2.397 \\
\mathrm{~kg} / \mathrm{m}^{3} \\
0.355<n<0.38 \\
4 \\
C=4.793 \\
\mathrm{~kg} / \mathrm{m}^{3} \\
0.305<n<0.32 \\
2 \\
\text { Xathan gum } \\
C=1.198 \\
0.472<n<0.48 \\
9 \\
C=2.397 \\
0.381<n<0.43 \\
9 \\
C=4.793 \\
0.277<n<0.34 \\
3 \\
\text { hydroxyethylc } \\
\text { ellulose } \\
(\mathrm{HEC}) \\
C=2.397 \\
0.6<n<0.668 \\
C=3.595 \\
0.494<n<0.54 \\
5 \\
C=4.793 \\
0.42<n<0.443 \\
\end{array}$ & $\begin{array}{l}\text { DR of polymer } \\
\text { solutions decreases } \\
\text { with the curvature } \\
\text { ratio. } \\
\text { Xathan and PHPA } \\
\text { yielded the best DR } \\
\text { properties. HEC } \\
\text { resulted in no DR. } \\
\text { Higher DR with } \\
\text { smallest } \\
\text { diameters. } \\
\text { For the largest tube } \\
\text { diameter, higher } \\
\text { polymer } C \text { decreased } \\
\text { the onset of the DR } \\
\text { whilst the opposite } \\
\text { effect was reported } \\
\text { for the smallest tube } \\
\text { diameter. }\end{array}$ \\
\hline $\begin{array}{l}\text { Shah et al. } \\
\text { Experimental }\end{array}$ & 2006 & $\begin{array}{c}d_{t}=11 \mathrm{~mm} \\
D_{c}=35.60,57.24,109.97 \mathrm{~m} \\
\mathrm{~m} \\
\delta=0.01,0.019,0.031 \\
N=3,6 \\
22,000<R_{s}<155,000 \\
\text { Turbulent }\end{array}$ & $\begin{array}{c}\text { For } \\
0.01<C<0.07 \\
\% \text { fluid is } \\
\text { assumed to be } \\
\text { Newtonian. } \\
\text { Non- } \\
\text { Newtonian } \\
\text { viscoelastic } \\
\text { fluid for } \\
C>0.07 \% \text {. } \\
\text { Solvent: } \\
\text { Water }\end{array}$ & $\begin{array}{l}\text { Nalco ASP- } \\
820 \text { (PHPA) } \\
0.01<V C<0.1 \\
5 \% \\
0.814<n<1.00\end{array}$ & $\begin{array}{l}\text { Optimum } V C \text { of } \\
\text { ASP- } 820 \text { is } 0.07 \% \text {. } \\
\text { At } 0.07 \% \text {, ASP- } 820 \\
\text { yields a DR of } 75 \% \\
\text { in straight tube and } \\
65 \% \text { in coiled tube, } \\
\text { ceteris paribus. } \\
\text { Increase in flow rate } \\
\text { increases the DR } \\
\text { while the opposite } \\
\text { effect was reported } \\
\text { for an increase in } \\
\text { curvature. } \\
\text { An increase in the } \\
\text { polymer } C \text { or } \\
\text { curvature ratio delays } \\
\text { the onset if DR. }\end{array}$ \\
\hline
\end{tabular}




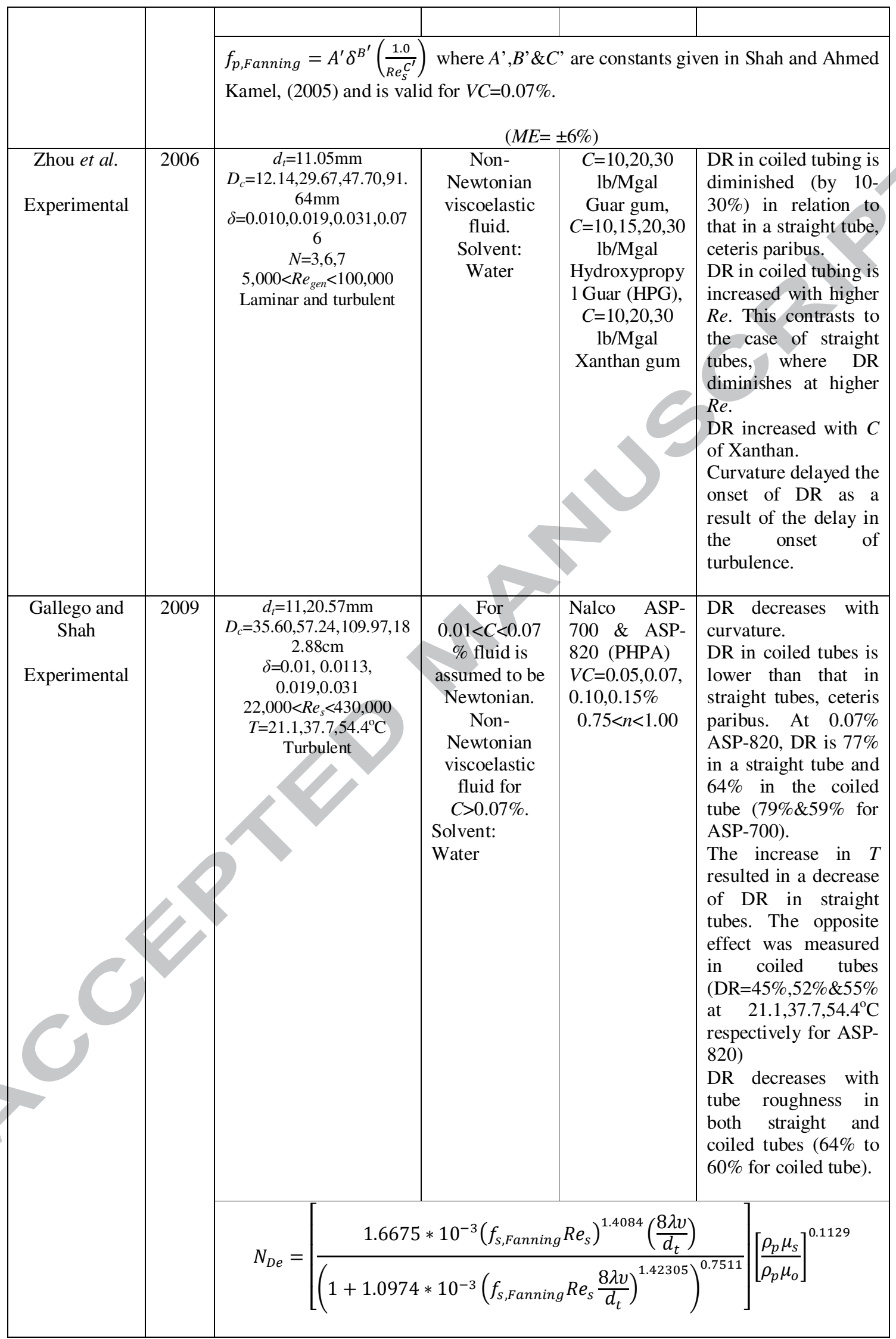




\begin{tabular}{|c|c|c|c|c|c|}
\hline & & \multicolumn{4}{|c|}{$\begin{array}{c}N_{D e}=\left(\frac{f_{s, \text { Fanning }}}{f_{p, \text { Fanning }}}\right)^{2}-1 \\
(M E= \pm 10 \%)\end{array}$} \\
\hline \multirow[t]{2}{*}{$\begin{array}{l}\text { Shah and } \\
\text { Zhou } \\
\text { Experimental }\end{array}$} & \multirow[t]{2}{*}{2009} & $\begin{array}{c}d_{t}=12 \mathrm{~mm} \\
D_{c}=146,356,572,1100 \\
\mathrm{~mm} \\
\delta=0.01,0.019,0.031,0.076 \\
N=3,3,7 \\
3,700<R e_{\text {gen }}<11,500 \\
\text { Laminar and turbulent }\end{array}$ & $\begin{array}{l}\text { Non- } \\
\text { Newtonian } \\
\text { viscoelastic } \\
\text { fluid. } \\
\text { Solvent: } \\
\text { Water }\end{array}$ & $\begin{array}{c}1.198<C<3.59 \\
5 \mathrm{~kg} / \mathrm{m}^{3} \\
\text { Guar gum, } \\
0.482<n<0.81 \\
9 \\
\text { Hydroxypropy } \\
1 \text { Guar (HPG), } \\
0.485<n<0.80 \\
5 \\
\text { Xanthan gum } \\
0.310<n<0.71 \\
7\end{array}$ & $\begin{array}{l}\text { Significant DR with } \\
\text { all three polymer } \\
\text { fluids. Curvature } \\
\text { reduces the DR and } \\
\text { delays the onset of } \\
\text { DR. }\end{array}$ \\
\hline & & \multicolumn{4}{|r|}{$\frac{1}{0.24575 \delta^{0.5}}$} \\
\hline \multirow[t]{2}{*}{$\begin{array}{l}\text { Ogugbue and } \\
\text { Shah } \\
\text { Numerical }\end{array}$} & \multirow[t]{2}{*}{2011} & $\begin{array}{c}\delta=0.3,0.5,0.6,0.8 \\
\varepsilon=0,0.25,0.5,0.75,0.96 \\
100<R e_{\text {gen }}<10,000 \\
\text { Laminar and turbulent }\end{array}$ & $\begin{array}{c}\text { Non- } \\
\text { Newtonian } \\
\text { viscoelastic } \\
\text { fluid. } \\
\text { Solvent: } \\
\text { Water }\end{array}$ & $\begin{array}{c}C=20,30,40,60 \\
\text { b/ } / \text { Mgal } \\
\text { Guar } \\
0.335<n<0.66 \\
6\end{array}$ & $\begin{array}{l}\text { DR increases with } \\
\text { increased eccentricity } \\
(50 \% \text { reduction for } \\
\text { fully eccentric } \\
\text { annular section) } \\
\text { Higher } C \text { increased } \\
\text { the frictional pressure } \\
\text { drop for laminar } \\
\text { flow. } \\
\text { For turbulent flow, all } \\
C \text { resulted in a } \\
\text { significant DR. }\end{array}$ \\
\hline & & & $\begin{array}{r}378 \frac{d_{\text {eit }}}{d_{\text {iot }}}+ \\
(M E=\end{array}$ & $\begin{array}{l}\frac{7374}{e_{\text {gen }}}+\frac{4042}{2 R e_{\text {gen }}} \\
5 \%)\end{array}$ & 0.00124 \\
\hline \multirow[t]{2}{*}{ Ahmed Kamel } & \multirow[t]{2}{*}{2011} & $\begin{array}{c}d_{t}=11 \mathrm{~mm} \\
D_{c}=579 \mathrm{~mm} \\
\delta=0.019 \\
T=22,35,38^{\circ} \mathrm{C} \\
20,000<R e<200,000 \\
P_{\max }=6.9 \mathrm{MPa} \\
\text { Turbulent }\end{array}$ & $\begin{array}{l}\text { Properties } \\
\text { assumed to be } \\
\text { quasi- } \\
\text { Newtonian. } \\
\text { Solvent: } \\
\text { Water }\end{array}$ & $\begin{array}{l}\text { Nalco ASP- } \\
820 \text { (PHPA) } \\
V C=0.07 \% \\
n \approx 1.00\end{array}$ & $\begin{array}{l}\text { DR in the range of } \\
30-80 \% \\
\text { At elevated } T \text {, the DR } \\
\text { effect is diminished } \\
\text { in straight tubes } \\
\text { while it remains } \\
\text { quasi- constant in } \\
\text { coiled tubes. }\end{array}$ \\
\hline & & \multicolumn{4}{|c|}{$\begin{array}{l}\frac{D R_{T}}{D R_{a}}=1.0 \\
(M E= \pm 2.1 \%)\end{array}$} \\
\hline
\end{tabular}

Table 1: Review of the experimental and numerical work

\section{Conclusions}


The studies reviewed have demonstrated that, due to the secondary flow, which increases with curvature, DR in coiled tubes is diminished when compared to straight tubes. However, a significant DR can be still be achieved with the introduction of: bubbles (9-25\%), surfactant (30-59\%) and polymer (circa 30-80\%) additives. DR is a strong function of the surfactant concentration and the air volume fraction whilst with polymer additives DR efficiency is dependent on the molecular weight, structure and solubility. DR is generally present in flows with $R e$ numbers in excess of the critical number. However, at elevated $R e$ numbers DR diminishes. This is due to the higher centrifugal forces (air bubbles and polymers) and mechanical degradation with high shear stress (surfactants). A number of authors have presented correlations for the calculation of the friction factor which are typically a function of the: curvature ratio, $R e$ and $D e$ numbers and the additive concentration.

Due to their low molecular weights, viscous properties and resilience to mechanical degradation, surfactant based fluids are generally considered to be superior to polymer based fluids. Hence, surfactants are suitable for a variety of applications such as district cooling and heating systems. A significant scope for future research has been elucidated for DR in coiled tubes with the injection of air bubbles (impact of bubble size and relation with the Lockhart and Martinelli correlation) and the application of a combination of methods, such as the use of polymer and surfactant additives with bubbly flow.

\section{Acknowledgments}

The authors of the current investigation would like to thank the University of Central Lancashire UK, for facilitating the completion of this study as well as the various authors who have been contacted during the course of this study.

\section{Notation List}

C concentration (ppm)

Cc non-dimensional surfactant concentration (-)

Cst empirical constant (-)

$d \quad$ tube internal diameter $(\mathrm{m})$

dr drag ratio (-)

$D \quad$ helix diameter $(\mathrm{m})$

De Dean number $\left(\operatorname{Re} \delta^{1 / 2}\right)(-)$

$D e^{\prime} \quad$ modified Dean number $\left(\operatorname{Re}{ }^{\prime} \delta^{1 / 2}\right)(-)$

$D e^{\prime}, \quad$ modified Dean number $\left(R e_{\text {gen }} \delta^{1 / 2}\right)(-)$

$D R \quad$ drag reduction $(\%)$

$f \quad$ friction factor (-)

FC friction coefficient (-)

$G z \quad$ Graetz number $(\operatorname{RePr} / z)(-)$

$G z$ ' modified Graetz number $\left(\operatorname{Re}^{\prime} \mathrm{Pr}^{\prime} / z\right)(-)$

$H \quad$ pitch (m)

$K \quad$ rheometric and technical consistency index $\left(\mathrm{Pa} \mathrm{s}^{\mathrm{n}}\right)$

$L \quad$ length (m)

$M E \quad$ mean error $(\%)$

$n \quad$ power law model flow behaviour index (-)

$N \quad$ number of turns (-)

$N_{D e} \quad$ Deborah number (-)

$N_{D e}$ ' modified Deborah number (-) 


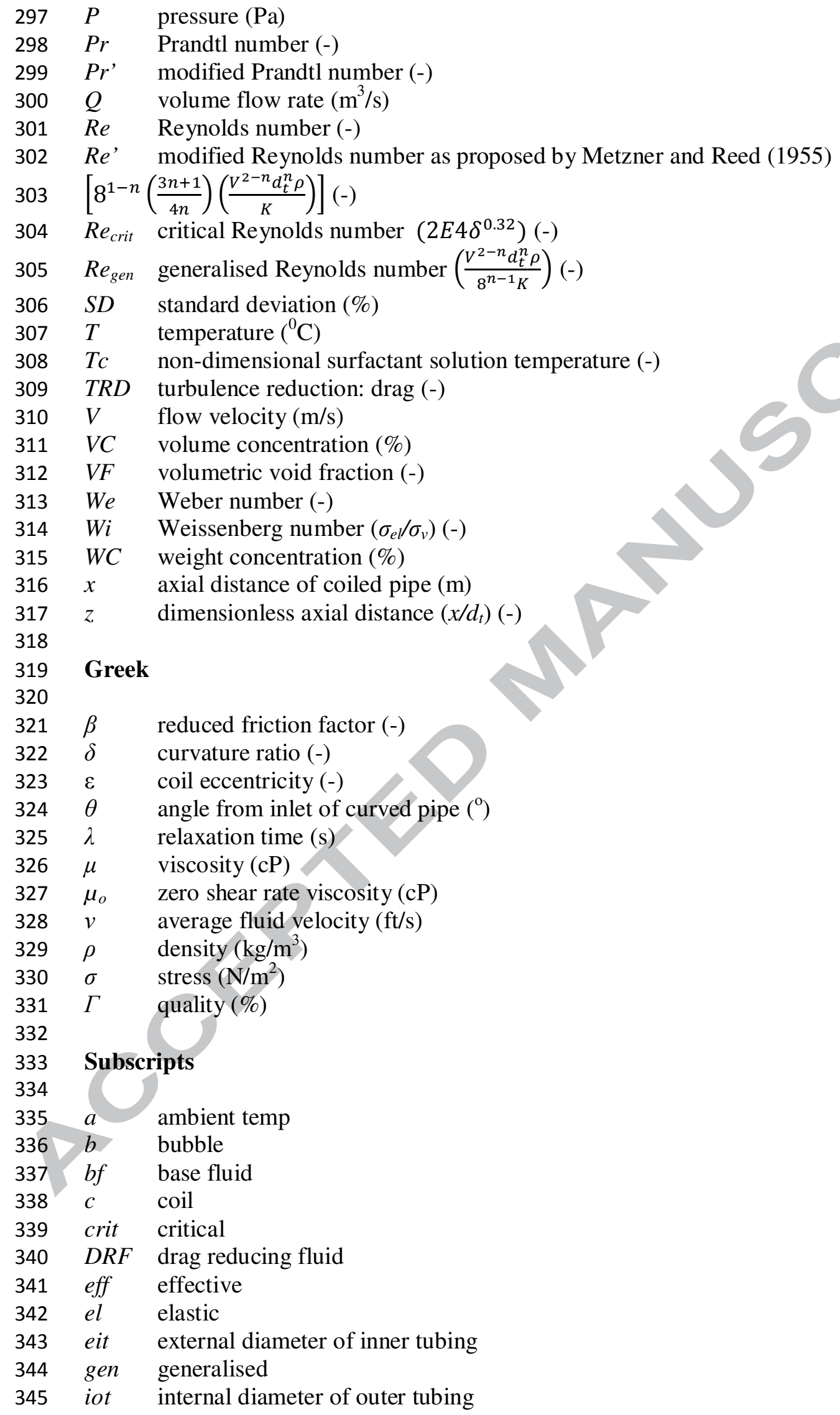




$\begin{array}{lll}346 & l & \text { liquid } \\ 347 & l m & \text { laminar } \\ 348 & m & \text { mean } \\ 349 & n d & \text { non-dimensional } \\ 350 & o & \text { zero } \\ 351 & p & \text { polymer solution } \\ 352 & s & \text { solvent } \\ 353 & s t & \text { straight tube } \\ 354 & t & \text { tube } \\ 355 & t b & \text { turbulent } \\ 356 & t p & \text { two-phase } \\ 357 & T & \text { elevated temperature } \\ 358 & v & \text { viscous }\end{array}$

360 References

361

362 Ahmed Kamel A.H., 2011, Drag reduction behaviour of polymers in straight and coiled 363 tubing at elevated temperature, Oil and Gas Business, 1, pp. 107-128.

364 Akagawa K., Tadashi S., Minoru U., 1971, Study on a gas-liquid two-phase flow in helically 365 coiled tubes, Bulletin of JSME, 14 (72), pp. 564-571

366 Al-Sarkhi A., Hanratty T.J., 2001, Effect of drag-reducing polymer on annular gas-liquid 367 flow in horizontal pipe, International Journal of Multiphase Flow, 27(7), pp. 1151-1162.

368 Al-Sarkhi A., Soleimani A., 2004, Effect of drag reducing polymers on two-phase gas-liquid 369 flows in a horizontal pipe, Transactions of the Institution of Chemical Engineers, Chemical 370 Engineering Research and Design 82(A12), pp.1583-1588.

371 Al-Sarkhi A., 2010, Drag reduction with polymers in gas/liquid-liquid flows in pipes: A 372 literature review, Journal of Natural Gas Science and Engineering, 2, pp. 41-48.

373 Aly W.I., Inaba H., Haruki N., Horibe A., 2006, Drag and heat transfer reduction phenomena 374 of drag-reducing surfactant solutions in straight and helical pipes, Special Issue on Boiling 375 and Interfacial Phenomena: Forced Convection, American Society of Mechanical Engineers, 376 128(8) pp. 800-810.

377 Aly W., 2014, Numerical study on turbulent heat transfer and pressure drop of nanofluid in 378 coiled tube-in-tube heat exchangers, Energy Conversion and Management, 79, pp. 304-316.

379 Azouz I., Shah S.N., Vinod P.S., Lord D.L.,1998, Experimental investigation of frictional 380 pressure losses in coiled tubing, Society of Petroleum Engineers: Production and Facilities, 381 13(2), Society of Petroleum Engineers-37328-PA.

382 Barnes H.A., Walters K., 1969, On the flow of viscous and elastico-viscous liquids through 383 straight and curved pipes, Proceedings of the Royal Society, London, A314(1516), pp. 85384

385 Bird R.B., Armstrong R.C., Hassager O., 1987, Dynamics of polymeric liquids, Second 386 Edition, John Wiley \& Sons, New York, Vol. I.

387 Broniarz-Press L., Rozanski J., Dryjer S., Woziwodzki S., 2002, Flow of the surfactant's 388 solutions in both straight and curved pipes, Proceedings of the $15^{\text {th }}$ International Congress of 389 Chemical Process Engineering, CHISA'2002, Praha. 
Broniarz-Press L., Rozanski J., Dryjer S., Woziwodzki S., 2003, Characteristics of the flow of the surfactants solutions in curved pipes, International Journal of Applied Mechanical Engineering, 8, Special Issue: ICER'2003 pp. 135-139.

Broniarz-Press L., Rozanski J., Rozanska S., 2007, Drag reduction effect in pipe systems and liquid falling film flow, Reviews in Chemical Engineering, 23(3-4), pp.149-245.

Clifford P.J., Sorbie K.S., 1985, The effects of chemical degradation on polymer flooding, The International Symposium on Oilfield and Geothermal Chemistry, Phoenix, Arizona, 9$11^{\text {th }}$ April.

Fsadni A.M., Whitty P.M., 2016, A review on the two-phase pressure drop characteristics in helically coiled tubes, Applied Thermal Engineering, 103, pp. 616-638.

Fujiwara A., Minato D., Hishida K., 2004, Effect of bubble diameter on modification of turbulence in an upward pipe flow, International Journal of Heat and Mass Transfer, 25(3), pp. 481-488.

Gallego F., Shah S.N., 2009, Friction pressure correlations for turbulent flow of drag reducing polymer solutions in straight and coiled tubing, Journal of Petroleum Science and Engineering, 65, pp. 147-161.

Gasljevic K., Matthys E.F., 1997, Experimental investigation of thermal and hydrodynamic development regions for drag-reducing surfactant solutions, Journal of Heat Transfer, 119(1), pp. 80-88.

Gasljevic K., Matthys E.F, 1999, Improved quantification of the drag reduction phenomenon through turbulence reduction parameters, Journal of Non-Newtonian Fluid Mechanics, 84(23), pp. 123-130.

Gasljevic K., Matthys E.F., 2009, Friction and heat transfer in drag-reducing surfactant solution flow through curved pipes and elbows, European Journal of Mechanics B/Fluids, 28, pp. 641-650.

Inaba H., Haruki N., Horibe A., 2000, Flow and heat transfer characteristics of water solution with drag reduction additive in curved tubes, Proceedings of the Symposium on Energy Engineering in the $21^{\text {st }}$ century, SEE 12(J6) pp. 723-730.

Inaba H., Aly W.I.A., Haruki N., Horibe A., 2005, Flow and heat transfer characteristics of drag reducing surfactant solution in a helically coiled pipe, Heat Mass Transfer, 41, (10), pp. 940-952.

Ito H., 1959, Friction factors for turbulent flow in curved pipes, ASME Journal of Basic Engineering, 81, pp. 123-134.

Kamel A.H., Shah S.S., 2013, Maximum Drag Reduction Asymptote for Surfactant-Based Fluids in Circular Coiled Tubing, Journal of Fluids Engineering, 135 (3) 031201-1:10.

Kelkar J.V., Mashelkar R.A., 1972, Drag reduction in dilute polymer solutions, Journal of Applied Polymer Sciences, 16, pp. 3047-3062.

Kostic M., 1994, On turbulent drag and heat transfer phenomena reduction and laminar heat transfer enhancement in non-circular duct flow of certain non-Newtonian fluids, International Journal of Heat and Mass Transfer, 37 (Suppl. 1) pp. 133-147.

Liu T.J., 1993, Bubble size and entrance length effects in void development in a vertcial channel, International Journal of Multiphase Flow, 19(1), pp.99-113. 
432 Mashelkar R.A., Devarajan G.V., 1976, Secondary flow of non-Newtonian fluids. II. 433 Frictional losses in laminar flow of purely viscous and viscoelastic fluids through coiled 434 tubes, Transactions of the Institution of Chemical Engineers, 54, pp. 108-114.

435 McCormick M.E., Bhattacharya R., 1973, Drag reduction of a submersible hull by 436 electrolysis, Naval Engineering Journal, 85(2), pp. 11-16.

437 Merkle C.L., Deutsch S., 1992, Microbubble drag reduction in liquid turbulent boundary 438 layers, Applied Mechanics Reviews, 45(3), pp. 103-127.

439 Metzner A.B., Reed J.C., 1955, Flow of non-Newtonian fluids - correlation of the laminar, 440 transition and turbulent flow regions, American Institute of Chemical Engineers Journal, 1(4) 441 pp. 434-440.

442 Mohammed H.A., Narrein K., 2012, Thermal and hydraulic characteristics of nanofluid flow 443 in a helically coiled tube heat exchanger, International Communications in heat and Mass 444 Transfer, 39, pp. 1375-1383.

445 Moriguchi Y., Kato H., 2002, Influence of microbubble diameter and distribution on 446 frictional resistance reduction, Journal of Marine Science and Technology, 7, pp. 79-85.

447 Murai Y., Fukuda H., Oishi Y., Kodama Y., Yamamoto F., 2007, Skin friction reduction by 448 large air bubbles in a horizontal channel flow, International Journal of Multiphase Flow, 449 33(2) pp. 147-163.

450 Murai Y., 2014, Frictional drag reduction by bubble injection, Experiments in Fluids, $451 \quad 55: 1773$ pp. 1-28.

452 Nesyn G.V., Manzhai V.N., Shibayev V.P., 1989, Influence of temperature and the nature of 453 the solvent on the ability of polymers to lower the drag resistance of liquids, Polymer Science 454 U.S.S.R., 31(7) pp. 1546-1553.

455 Nouri N.M., Motlagh S.Y., Navidbakhsh M., Dalilhaghi M., Moltani A.A., 2013, Bubble 456 effect on pressure drop reduction in upward pipe flow, Experimental Thermal and Fluid 457 Science, 44, pp. 592-598.

458 Ogugbue C.C., Shah S.N., 2011, Laminar and turbulent friction factors for annular flow of 459 drag-reducing polymer solutions in coiled-tubing operations, Society of Petroleum Engineers: 460 Drilling and Completion, 26(4) pp.506-518.

461 Oliver D.R., Asghar S.M., 1976, Heat transfer to Newtonian and viscoelastic liquids during 462 laminar flow in helical coils, Transactions of the Institution of Chemical Engineers, 54, pp. $463 \quad 218-224$.

464 Rao B.K., 1993, Turbulent heat transfer to viscoelastic fluids in helical passages, 465 Experimental Heat Transfer, 6(2), pp. 189-203.

466 Saffari H., Moosavi R., Gholami E., Nouri N.M., 2013, The effect of bubble in the pressure 467 drop reduction in helical coil, Experimental Thermal and Fluid Science, 51, pp. 251-256.

468 Saffari H., Moosavi R., 2014, Numerical study of the influence of geometrical characteristics 469 of a vertical helical coil on a bubbly flow, Journal of Applied Mechanics and Technical 470 Physics, 55(6), pp.957-969.

471 Shah S.N., Zhou Y., 2001, An experimental study of drag reduction of polymer solutions in 472 coiled tubing, The University of Oklahoma, Coiled Tubing Consortium Annual Meeting, 473 Houston, Texas, Society of Petroleum Engineers: 68419. 
474 Shah S.N., Ahmed Kamel A.H., 2005, Drag reduction in straight and coiled tubing, The 475 University of Oklahoma, Coiled Tubing Consortium Annual Meeting, Houston, Texas.

476 Shah S.N., Kamel A., Zhou Y., 2006, Drag reduction in straight and coiled tubing - An 477 experimental study, Journal of Petroleum and Engineering, 53, pp. 179-188.

478 Shah S.N., Zhou Y., 2009, Maximum drag reduction asymptote of polymeric fluid flow in 479 coiled tubing, American Society of Mechanical Engineers, Journal of Fluids Engineering, 480 131(1) pp. 011201-1:9.

481 Shatat M.M.E., Yanase S., Takami T., Hyakutake T., 2009a, Drag reduction effects of micro482 bubbles in straight and helical pipes, Journal of Fluid Science and Technology, 4(1), pp.156483167.

484 Shatat M.M.E., Yanase S., Takami T., Hyakutake T., 2009b, Pressure drop characteristics of 485 water flow with micro-bubbles through helical pipes, Proceedings of the $6^{\text {th }}$ WSEAS 486 International Conference on Fluid Mechanics, ISSN: 1790-5095.

487 Shen X., Ceccio S.L., Perlin M., 2006, Influence of bubble size on micro-bubble drag 488 reduction, Experiments in Fluids, 41(3), pp. 415-424.

489 Sylvester N.D., Brill J.P., 1976, Drag-reduction in two-phase annular mist flow of air and 490 water, American Institute of Chemical Engineers Journal, 22(3), pp.615-617.

491 Toms B.A., 1948, Some observations on the flow of linear polymer solutions through straight 492 tubes at large Reynolds Numbers, Proceedings of the First International Congress on 493 Rheology, North Holland, Amsterdam.

494 Wang F., Li Z., Chen H., Li S., 2015, Foam fluid flow analysis in helical coiled tubing using 495 CFD, Procedia Engineering, 126, pp. 696-700.

496 Weber M., Steiff A.S., Weinspach P.M., 1991, Heat transfer and pressure loss in flow of 497 surfactant solutions in coiled pipes, Forschung im Ingenieurwesen, 57(4), pp. 112-118 (In 498 German).

499 Wei T., Willmarth W.W., 1992, Modifying turbulent structure with drag-reducing polymer 500 additives in turbulent channel flows, Journal of Fluid Mechanics, 245, pp. 619-641.

501 Zhou Y., Shah S.N., Gujar P.V., 2006, Effect of coiled tubing curvature on drag reduction of 502 polymeric fluids, Society of Petroleum Engineers: Production and Operations, 21(1), pp.134503141. 


\section{Highlights}

- Review on pressure drop reduction studies in helically coiled tubes

- Air bubbles, surfactant and polymer additives are effective in diminishing drag

- Drag reduction is diminished in relation to straight tubes

- Drag reduction is predominantly evident in turbulent flow

- Drag reduction diminishes with higher coil curvatures and excessive $R e$ numbers 